\title{
Enhancing the stress responses of probiotics for a lifestyle from gut to product and back again
}

\author{
Susan Mills ${ }^{1}$, Catherine Stanton ${ }^{1,3}$, Gerald F Fitzgerald ${ }^{2,3}$, R Paul Ross $^{1,3^{*}}$ \\ From 10th Symposium on Lactic Acid Bacterium \\ Egmond aan Zee, the Netherlands. 28 August - 1 September 2011
}

\begin{abstract}
Before a probiotic bacterium can even begin to fulfill its biological role, it must survive a battery of environmental stresses imposed during food processing and passage through the gastrointestinal tract (GIT). Food processing stresses include extremes in temperature, as well as osmotic, oxidative and food matrix stresses. Passage through the GIT is a hazardous journey for any bacteria with deleterious lows in $\mathrm{pH}$ encountered in the stomach to the detergent-like properties of bile in the duodenum. However, bacteria are equipped with an array of defense mechanisms to counteract intracellular damage or to enhance the robustness of the cell to withstand lethal external environments. Understanding these mechanisms in probiotic bacteria and indeed other bacterial groups has resulted in the development of a molecular toolbox to augment the technological and gastrointestinal performance of probiotics. This has been greatly aided by studies which examine the global cellular responses to stress highlighting distinct regulatory networks and which also identify novel mechanisms used by cells to cope with hazardous environments. This review highlights the latest studies which have exploited the bacterial stress response with a view to producing next-generation probiotic cultures and highlights the significance of studies which view the global bacterial stress response from an integrative systems biology perspective.
\end{abstract}

\section{Introduction}

To suggest that probiotic bacteria have entered the realm of the highly exploited bacterial groups is an understatement. Moreover, man's expectations of probiotic bacteria have perhaps become the most demanding for any bacterial group to date. With numerous health-promoting attributes, many of which have been scientifically validated in animal and human clinical trials, probiotic bacteria have become an integral element to everyday healthy living. Indeed, the global market for probiotics is estimated to exceed US $\$ 28.8$ billion by 2015 [1]. Probiotic bacteria generally execute their biological role in the gut, which can involve a plethora of effects from immunomodulation to production of bioactive metabolites, all of which have dramatic consequences for disease evasion [2-4]. The present target of any probiotic food product in terms of probiotic cell numbers is to have up to $10^{7}$ colony forming units

\footnotetext{
* Correspondence: paul.ross@teagasc.ie

${ }^{1}$ Teagasc Food Research Centre, Moorepark, Fermoy, Co. Cork, Ireland Full list of author information is available at the end of the article
}

(cfu)/g at the end of its shelf life [5], although it should be emphasized that this will probably become strain and application specific as new clinical evidence emerges supporting health claims. Thus, before probiotic bacteria can even begin to fulfill their physiological role in the gut, the bacteria themselves must endure a number of stresses to ensure they reach the target site in adequate numbers to elicit an effect. These stresses can be considered in two distinct contexts; firstly, probiotic bacteria must be processed in suitable form to enable oral consumption and secondly the bacteria must be able to withstand the harsh conditions imposed during passage through the gastrointestinal tract (GIT).

\section{From gut...}

Potential probiotic cultures have been isolated from a variety of sources including animal, human and food sources. However, there is now growing evidence that strains are host specific [6] and for that reason it is generally recommended that human isolates should be used for human applications as a starting point. In this 
respect human strains have been isolated from various sites from oral to stool samples.

\section{To product...}

In terms of processing, probiotics are commonly grown to high numbers before undergoing a drying process to produce a high-cell density probiotic powder. This can then be added to a specific carrier, such as a dairy product, which is stored under suitable conditions. Probiotic robustness can be compromised even in the initial growing stages. Indeed, Muller et al. [7] recently demonstrated that the nutrient composition of the growth medium can have a significant effect on the technological properties of probiotics by altering membrane composition and morphology. The presence of linoleic and linolenic acids in a minimal growth medium reduced the acid and heat tolerance of Lactobacillus johnsonii NCC533 by $6-$ and 20 -fold, respectively [7]. The stresses encountered during drying include extremes in temperatures, from very high temperatures in spray-drying, to very low-temperatures during freeze drying and storage, as well as osmotic and oxidative stresses. During spraydrying temperatures can reach as high as $200^{\circ} \mathrm{C}$ [8] and while the exposure time for the cells is extremely short, the integrity of viable bacterial cells can be severely compromised. The cytoplasmic membrane is the primary target for heat damage, resulting in damage to fatty acids and aggregation of proteins, however, intracellular proteins, ribosomes and RNA can also be duly impaired $[9,10]$. In addition to heat stress, spray-drying also exposes cells to osmotic stress, dehydration and oxidative stress [10]. At the other end of the scale, cells are typically frozen at $-196^{\circ} \mathrm{C}$ during freeze-drying, and then dried by sublimation under high vacuum [11-13]. Freeze-drying is less harsh on cells than spray-drying resulting in higher cell viability [14]. However, the low temperature still compromises cellular integrity where the main consequences include reduction in membrane fluidity, increases in the rate of DNA strand breakage, stabilization of RNA and DNA secondary structures which in turn alters transcription, translation and replication [15]. Ribosome functions, protein folding and enzyme activity are also disturbed at low temperatures $[16,17]$. Oxygen stress can affect probiotic bacteria at various stages of their production, from fermentation to drying and even storage etc. While oxygen itself does not damage the cells, its partial reduction to water generates reactive oxygen species (the superoxide anion radical $\mathrm{O}_{2}{ }^{-}$, the hydroxyl radical $\mathrm{OH}^{*}$, and hydrogen peroxide $\mathrm{H}_{2} \mathrm{O}_{2}$ ) which can lethally damage proteins, lipids and DNA $[5,18]$. Cysteine in the active sites of enzymes can also be a target for oxidation [19]. Oxygen sensitivity can be particularly problematic for bifidobacteria, although variations have been observed across this species in terms of oxygen tolerance [20,21]. Indeed, two species isolated from porcine caecum, Bifidobacterium aerophilum and Bifidobacterium psychroaerophilum, were found to be aerotolerant with the ability to grow on agar-medium under aerobic conditions [22]. Certain strategies have proven successful in terms of reducing the effects of oxygen toxicity. For example, electro-reduction, de-aeration or addition of reducing agents to non-fermented pasteurized milk was shown to enhance the viability of bifidobacteria during extended storage [23]. In fermented milk, co-cultivation of Bifidobacterium longum BB536 with Lactococcus lactis ssp. lactis MCC866, improved the survival of the bifidobacterial strain [24]. In this case, L. lactis ssp. lactis MCC866 was found to express several genes involved in protection against active oxygen species at higher levels during refrigerated storage, compared to non-effective lactococcal strains. Moreover, the food matrix itself can impose multiple stresses on bacterial survival. For example, several genes contributing to stress-related functions were induced in the commercial meat starter Lactobacillus sakei $23 \mathrm{~K}$ during meat fermentation [25]. The global transcriptional response of Lactobacillus reuteri ATCC 55730 to the sourdough environment also revealed the up-regulation of various stress-related genes during sourdough fermentation [26]. Probiotic viability in Cheddar cheese was found to be markedly reduced when cells were added just before cheddaring but cell losses were halved when the probiotic was added to milk before renneting [27]. Moreover, in the same study salt was found to negatively compromise cell viability. However, food matrix stresses may also contribute to the overall survival of probiotic bacteria. Leverrier et al. [28] demonstrated that freeze-dried propionibacteria included at the beginning of milk fermentation were much more robust when exposed to acid and bile salt stresses as opposed to reconstituted freeze-dried cells which were dramatically injured under the same stress conditions.

\section{And back again...}

Passage of probiotics through the mammalian GIT is a hazardous journey, with the initial stages designed to jeopardize the survival of pathogenic microorganisms. The principal stresses include shifting $\mathrm{pH}$ encountered in the stomach resulting from gastric acid, as well as bile, a digestive secretion of the hepatic system which serves to emulsify and solubilize lipids and lipid soluble vitamins for metabolism, and steep gradients of oxygen. Exposure to acid negatively affects the proton motive force (PMF) across the membrane as a result of the accumulation of protons inside the cell [29]. In addition to cell membrane structural damage, acid stress causes damage to DNA and proteins [15]. Exposure to bile 
disrupts the integrity of the cell membrane, affects DNA, RNA structure formation as well as protein folding and exposes the cell to oxidative stress and low intracellular $\mathrm{pH}[30,31]$.

\section{The probiotic stress response}

Bacterial cells are naturally equipped with a plethora of defense mechanisms to enhance survival in hostile environments [15,29,32-34]. These include chaperone proteins which assist the folding of misfolded proteins, proteases which degrade proteins which are irreversibly damaged, transport systems to maintain correct osmolarity, catalases and superoxide dismutases to tackle reactive oxygen species, as well as proton pumps, decarboxylases and transporters to combat decreases in intracellular $\mathrm{pH}$ [29] (Table 1, Figure 1). Understanding the intricacies of these systems provides scientists with a plethora of molecular tools to improve bacterial endurance. For example, a recent patent was filed describing numerous stress-related proteins of the probiotic strain Lactobacillus acidophilus and genetic engineering approaches which may be used to improve the stress response of the strain [35].

The aim of this review is to highlight the latest studies which take advantage of the bacterial stress response to produce 'super-fit' bacteria through genetic manipulation. Moreover, the upsurge in genome sequencing alongside systems biology approaches is now enabling scientists to view the global cellular response to the stresses encountered during processing and transit in the gut. As well as providing a deeper understanding of the probiotic stress response, this information is generating a wealth of novel molecular tools, which may find themselves as central players in the science of probiotic enhancement in the future.

\section{Taking advantage of the bacterial stress response - genetic manipulation \\ Exploiting probiotic stress responses}

It is well accepted that adaptation to a sub-lethal dose of a specific physical or chemical stress can dramatically improve subsequent performance in compromising environments and as a consequence is a popular strategy to increase both the technological and gastrointestinal robustness of a strain. The success of this strategy is owed to the induction of the bacterial stress response during the adaptation process whereby a specific system may be induced with the result that the cells survive a previously lethal dose of the same stress, or a more general system may be targeted enabling cross-protection against a range of stresses. For example, in order to improve the viability of the probiotic strain Lactobacillus paracasei NFBC 338 during spray-drying Desmond et al. [36] demonstrated that pre-stressing the culture by exposure to $52^{\circ} \mathrm{C}$ for 15 minutes improved survival of the strain 700 -fold (in reconstituted skim milk) during heat stress and 18 fold during spray-drying compared to un-adapted cells. Exposure to salt stress also afforded a level of thermotolerance. Indeed, following exposure to $0.3 \mathrm{M} \mathrm{NaCl}$ survival of the strain improved by 16 -fold during spray-drying [36]. A proteomics analysis of the biological response of $L b$. paracasei NFBC 338 to heat adaptation revealed an altered level of expression of at least 12 proteins, where expression of the chaperone GroEL was most dramatically induced in the test culture [37]. GroEL works in concert with its co-chaperone GroES where the complex ensures the correct folding of proteins in an ATP-regulated manner under normal growth conditions and under conditions of stress [29]. The genes encoding GroESL are negatively regulated by HrcA, which binds to a pallindromic operator sequence called CIRCE (controlling inverted repeat of chaperone expression). Subsequently, overexpression of the groESL operon of $L b$. paracasei NFBC 338 using the nisin controlled expression system in $L b$. paracasei resulted in increased survival during exposure to stressful levels of heat, salt and butanol [37]. Moreover, Lb. paracasei over-expressing GroESL exhibited 10-fold better survival during spray-drying and 2-fold better survival during freeze-drying demonstrating that the GroESL chaperone is an effective molecular target for enhancing the technological performance of probiotic lactobacilli during spray-drying [5] (Figure 2). Interestingly, mRNA transcripts of the chaperones GroEL and DnaK were recently up-regulated 2-fold by down-regulating the negative regulator HrcA using anti-sense RNA technology [Kearney et al. unpublished]. However, although the anti-sense strain exhibited an increased exponential growth rate compared to the control, the anti-sense strain remained as sensitive as the control strain to heat, acid, bile solvent and osmotic stresses.

The ATP-independent chaperones, the small heat shock proteins (sHsps), have also been associated with enhanced bacterial survival during stress. While these proteins are not involved in protein re-folding they are necessary for normal cellular functions including growth, stability of DNA and RNA and they prevent the formation of inclusion bodies [38-40]. Heat, cold and ethanol stresses were previously shown to enhance the expression of the heat shock genes hsp18.5, hsp19.3 and hsp18.55 encoded on the genome of Lactobacillus plantarum[41,42]. Interestingly, hsp18.5 and hsp19.3 genes were preceded by an inverted repeat at the 5 ' end with homology to the operator sequence CIRCE [41] whereas the 5' region preceding hsp18.55 revealed the presence of putative cis elements able to bind alternative sigma factor $\sigma^{\mathrm{B}}[42]$. Inactivation of $h s p 18.55$ revealed that the protein encoded by the gene may be involved in the 
Table 1 Examples of Proteins and Genes Involved in the Stress Responses of Probiotics

\begin{tabular}{|c|c|c|c|c|}
\hline Stress & Protein/Gene/System (General Role/Description) & Fold Induction & Strain & Ref \\
\hline Heat & GroEL (chaperone protein) & +49.1 & Lactobacillus paracasei NFBC338 & {$[37]$} \\
\hline $\begin{array}{l}\text { Heat } \\
\text { Osmotic }\end{array}$ & GroEL (chaperone protein) & $\begin{array}{l}+15 \\
+3\end{array}$ & Lactobacillus rhamnosus HN001 & [118] \\
\hline Heat & $\begin{array}{l}\text { CIpL1 (Clp ATPase family, members act as chaperones } \\
\text { and regulators of proteolysis) }\end{array}$ & +20 & Lactobacillus rhamnosus E800 & [119] \\
\hline Heat, Cold, Ethanol & $\begin{array}{l}\text { hsp18.5 (heat shock protein) } \\
\text { hsp19.3 (heat shock protein) }\end{array}$ & nd & Lactobacillus plantarum Lp90 & [41] \\
\hline Heat, Cold, Ethanol & hsp18.55 (heat shock protein) & nd & Lactobacillus plantarum Lp90 & {$[42]$} \\
\hline Heat & $\begin{array}{l}\text { DnaK (chaperone protein) } \\
\text { GroEL (chaperone protein) } \\
\text { ClpE (Clp ATPase family, members act as chaperones } \\
\text { and regulators of proteolysis) }\end{array}$ & $\begin{array}{l}+4.4 \\
+3.8 \\
+1.7\end{array}$ & Lactobacillus gasseri ATCC 33323 & [120] \\
\hline Heat & FtsH (protease and chaperone activity) & +8 & Lactobacillus plantarum WCFS1 & [121] \\
\hline Heat & $\begin{array}{l}\text { HtrA (protease and chaperone activity) } \\
\text { GroEL (chaperone protein) } \\
\text { DnaK (chaperone protein) } \\
\text { GrpE (chaperone protein) }\end{array}$ & $\begin{array}{l}+10-+15 \\
+5-+10 \\
+10-+15 \\
+2-+5\end{array}$ & Bifidobacterium longum 3A & [122] \\
\hline Heat & $\begin{array}{l}\text { groEl-cspA, (chaperone protein-cold shock protein) } \\
\text { groES (chaperone protein) }\end{array}$ & $\begin{array}{l}+12 \\
+8\end{array}$ & Bifidobacterium breve UCC 2003 & [123] \\
\hline Heat & $\begin{array}{l}\text { ClpC (Clp ATPase family, members act as chaperones } \\
\text { and regulators of proteolysis) }\end{array}$ & +15 & Bifidobacterium breve UCC 2003 & [124] \\
\hline Heat & $\begin{array}{l}c \mid p P \text { operon: } c|p P 1, c| p P 2 \text { (Clp ATPase family, members } \\
\text { act as chaperones and regulators of proteolysis) }\end{array}$ & +15 & Bifidobacterium breve UCC 2003 & [125] \\
\hline $\begin{array}{l}\text { Heat } \\
\text { Osmotic }\end{array}$ & hsp20 (heat shock protein) & $\begin{array}{l}+28 \\
+25\end{array}$ & Bifidobacterium breve UCC 2003 & [126] \\
\hline Temperature downshift & cspA (cold shock protein) & +20 & Lactobacillus bulgaricus VI104 & [127] \\
\hline Cold & $\begin{array}{l}\text { ClpP (Clp ATPase family, members act as chaperones } \\
\text { and regulators of proteolysis) } \\
\text { Pyruvate kinase } \\
\text { Glycoprotein endopeptidase }\end{array}$ & $\geq 2$ & Lactobacillus acidophilus RD758 & [128] \\
\hline Temperature downshift & $\operatorname{cspl}$ (cold shock protein) & +17 & Lactobacillus plantarum NC8 & [46] \\
\hline Osmotic & $\begin{array}{l}\text { dnaK operon: dnaK, grpE, dnaJ (chaperones), ORF1 } \\
\text { (similarity to predicted heat-controlled transcriptional } \\
\text { regulators of Mer family) }\end{array}$ & $+15,+14$ & Bifidobacterium breve UCC 2003 & [129] \\
\hline Osmotic & $d n a J_{2}$ (chaperone) & +4.5 & Bifidobacterium breve UCC 2003 & [130] \\
\hline Oxygen & NADH oxidase \& NADH peroxidase & & $\begin{array}{l}\text { Lactobacillus acidophilus } 2400 \\
\text { Lactobacillus acidophilus } 2409 \\
\text { Bifidobacterium lactis } 1941 \\
\text { Bifidobacterium pseudolongum } 1944 \\
\text { Bifidobacterium longum } 1944\end{array}$ & [103] \\
\hline Oxygen & $\begin{array}{l}\text { AhpC (alkyl hydroperoxide reductase C22) } \\
\text { PNDR (Pyridine nucleotide-disulfide reductase) } \\
\text { Dps (DNA-binding ferritin-like protein) } \\
\text { NrdA (ribonucleotide reductase) } \\
\text { MutT1 (NTP phosphohydrolases) }\end{array}$ & $\begin{array}{l}+10 \\
+2 \\
+1.7 \\
+2 \\
+1.8\end{array}$ & Bifidobacterium longum BBMN68 & [104] \\
\hline Bile & $\begin{array}{l}\text { HtrA (protease and chaperone activity) } \\
\text { DnaK (chaperone protein) } \\
\text { GroEL (chaperone protein) }\end{array}$ & $\begin{array}{l}+1.5-+2 \\
+1.5-+2 \\
+1.5-+2\end{array}$ & Bifidobacterium longum 3A & [122] \\
\hline Bile & Bsh1 (bile salt hydrolase) & & Lactobacillus plantarum WCFS1 & [131] \\
\hline Bile & Ctr (cholate transporter) & & Bifidobacterium longum NCIMB 702259T & [132] \\
\hline Acid & $\begin{array}{l}\text { cIpL (Clp ATPase family, members act as chaperones } \\
\text { and regulators of proteolysis) } \\
\text { Ir1516 (putative cell wall-altering esterase) }\end{array}$ & $\begin{array}{l}+2-+3 \\
>5\end{array}$ & Lactobacillus reuteri ATCC 55730 & [133] \\
\hline Acid & GrpE (chaperone protein) & $>3.5$ & Lactobacillus sanfranciscensis CB1 & [134] \\
\hline Acid & LBAI524HK (histidine kinase) & & Lactobacillus acidophilus NCFM & [135] \\
\hline Acid & $\begin{array}{l}F_{0} F_{1} \text {-ATPase operon (involved in ATP synthesis and } \\
\text { proton extrusion) }\end{array}$ & +2 & Lactobacillus acidophilus NCFM/N2 & [136] \\
\hline Acid & $\begin{array}{l}F_{0} F_{1} \text {-ATPase operon (involved in ATP synthesis and } \\
\text { proton extrusion) }\end{array}$ & +15 & Bifidobacterium lactis DSM10140 & [137] \\
\hline
\end{tabular}




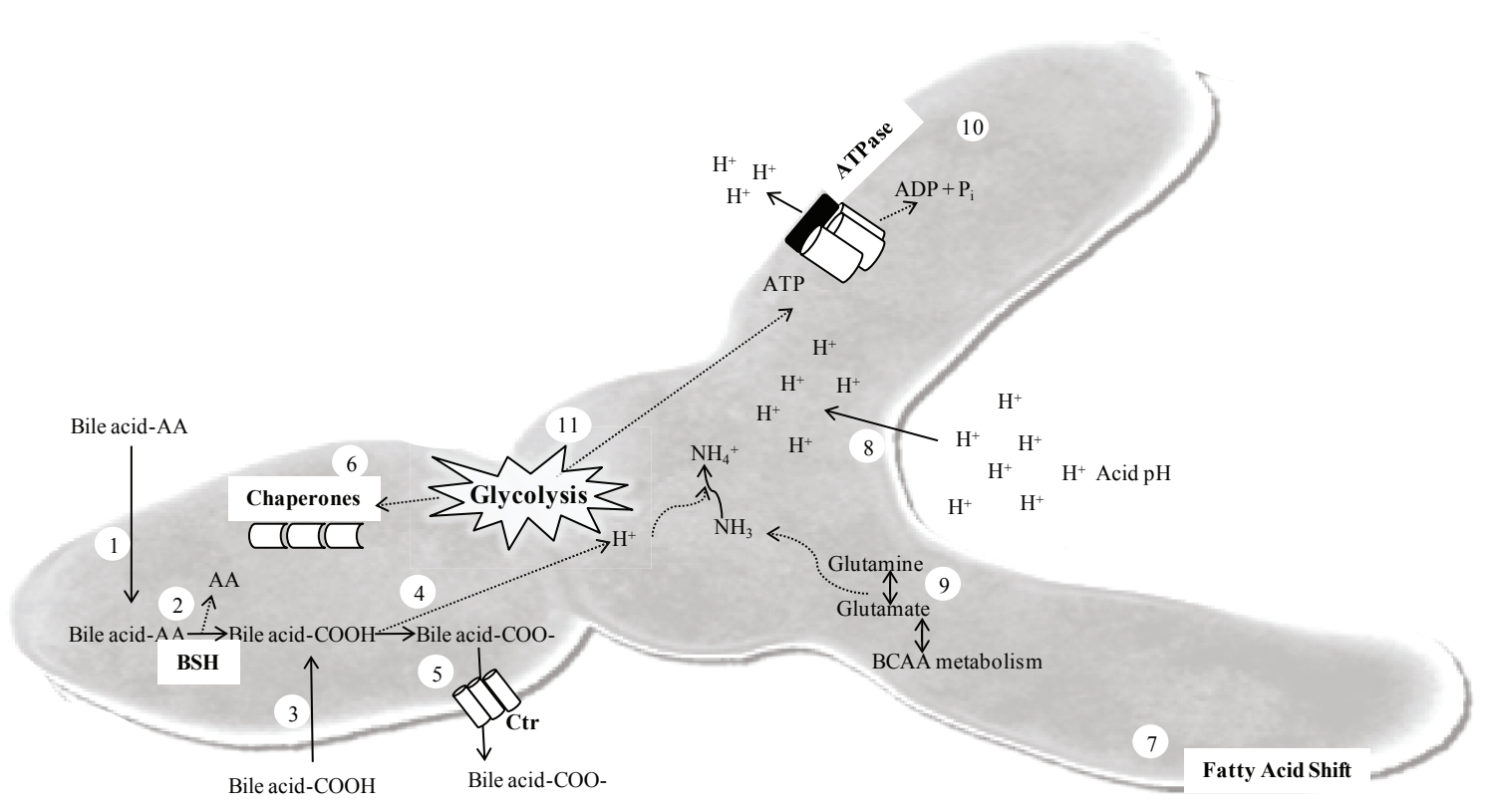

Figure 1 Diagrammatic representation of the main stress responses to acid $\mathrm{pH}$ and bile salt in bifidobacteria. (1) Conjugated bile acids enter the bacterial cytoplasm and are cleaved by BSH (bile salt hydolase) (2) releasing one amino acid and one de-conjugated bile acid moiety. (3) Deconjugated bile acid can also enter the cell by passive diffusion and becomes deprotonated (4). (5) lonized bile salts are non-permeable and are excreted by the action of certain transporters e.g. Ctr (cholate transporter) of Bifidobacterium longum. (6) Synthesis of molecular chaperones is also increased and a shift in fatty acid composition of cell membrane can occur (7). Exposure to acid pH or bile salt deprotonation results in acidification of the cytoplasm (8). This can be counteracted by the production of ammonia from glutamine deamination (9) or pumping of protons from the cell by the $F_{1} F_{0}$-ATPase (10). ATP required for driving these systems is generated through glycolysis (11) (reproduced from Sanchez et al. [138]).

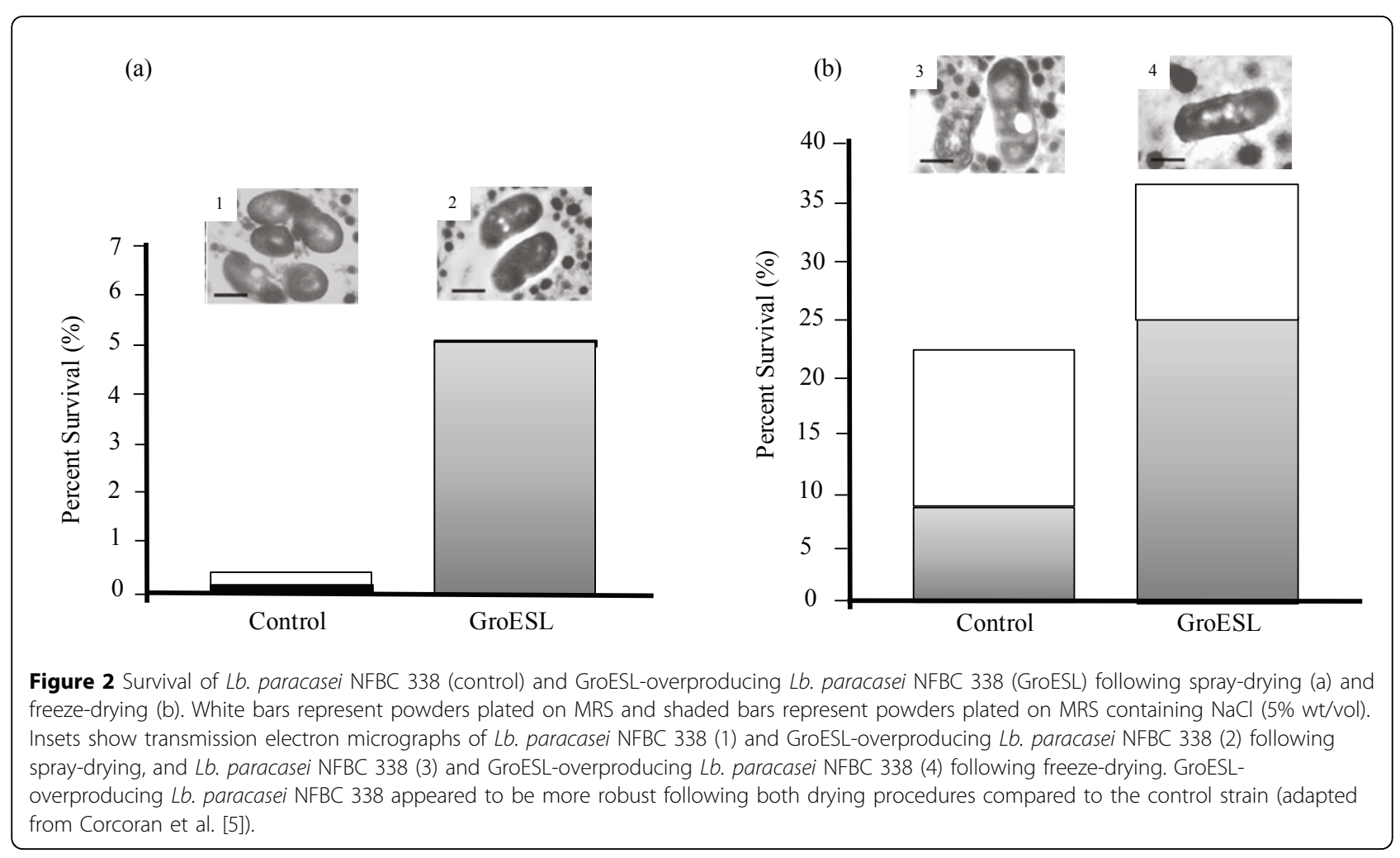


recovery of stressed cells during the early stage of high temperature stress [43]. Indeed, the $\Delta h s p 18.55$ mutant strain displayed a longer lag phase under conditions of short intense heat stress $\left(50^{\circ} \mathrm{C}\right)$. Physical parameters were also disturbed in the mutant strain including membrane fluidity and surface properties. Overproduction of each of the three heat shock proteins in Lb. plantarum improved the growth of the genetically-modified cultures during heat shock $\left(37^{\circ} \mathrm{C}\right.$ or $\left.40^{\circ} \mathrm{C}\right)$ and cold shock $\left(12^{\circ} \mathrm{C}\right)$ and overproduction of Hsp18.55 and Hsp19.3 also improved survival during solvent stress $(1 \% \mathrm{v} / \mathrm{v}$ butanol or $12 \% \mathrm{v} / \mathrm{v}$ ethanol) [44].

Cold shock proteins (Csps) are induced as a result of cold shock pre-treatment where they have been associated with the stabilisation of mRNA [45]. Three induced Csps were previously identified in $L b$. plantarum following cold shock treatment, namely CspL, CspP, CspC [46]. Overproducing each of the three proteins in $L b$. plantarum resulted in improved performance during treatments involving a down-shift in temperature and under conditions of nutritional deprivation [47]. For example, overproduction of CspC led to faster growth when stationary phase cells were added to fresh medium when compared to controls, suggesting a role for CspC in nutrient adaptation. Cells overproducing CspL did not suffer a reduction in growth rate following exposure of exponentially growing cells to cold shock $\left(8^{\circ} \mathrm{C}\right)$, while overproduction of CspP resulted in enhanced survival during 6 cycles of freeze-thawing at $-80^{\circ} \mathrm{C}$ resulting in a 4 -fold survival level.

Exploiting stress responses of pathogenic microorganisms Patho-biotechnology is a relatively new concept which aims to exploit stress response systems of pathogenic bacteria for biotechnological and biomedical purposes [48]. Indeed, pathogenic bacteria can be a rich reservoir of sophisticated mechanisms which ensure bacterial endurance in some of the most stressful environments including the host immune system or those encountered during food processing. For example, certain bacterial species accumulate protective compounds called compatible solutes as part of the stress response [49]. These compounds are generally highly soluble with no net charge at physiological $\mathrm{pH}$ [50]. Within the cells they serve as osmotic balancers [51] but also serve to protect enzyme function against the stresses of high temperature, salinity, freeze-thawing and drying [52,53]. The trimethylammonium compound glycine betaine is used as a compatible solute by the majority of bacteria including Listeria monocytogenes[54]. In this respect, the secondary glycine betaine transporter of L. monocytogenes, BetL, has been shown to improve survival of the strain in certain foods [55], as well as improve its osmotolerance, cryotolerance and barotolerance [56-58].
Interestingly, heterologous expression of BetL from $L$. monocytogenes in the probiotic strain Lactobacillus salivarius UCC118 using the nisin controlled expression system resulted in a genetically modified strain with improved resistance to numerous stresses [54]. The BetL $^{+}$strain accumulated 65 times more betaine than the BetL ${ }^{-}$strain and was capable of growth in $7 \% \mathrm{NaCl}$, unlike the control which was unable to grow efficiently at the same concentration. Repeated freeze-thaw cycles at $-20^{\circ} \mathrm{C}$ or $-70^{\circ} \mathrm{C}$ demonstrated that the $\mathrm{BetL}^{+}$strain was two logs greater than the control at $-20^{\circ} \mathrm{C}$ and 0.5 logs greater at $-70^{\circ} \mathrm{C}$. The barotolerance of the test strain also improved yielding a 2-log increase over the control strain following exposure to $350 \mathrm{MPa}$. Moreover, the BetL ${ }^{+}$strain survived freeze-drying and spraydrying much more efficiently than the control with a $36 \%$ survival level for test versus $18 \%$ for control following freeze-drying and a $1.4 \%$ survival level for test versus $0.3 \%$ for control after spray-drying. Cloning the $L$. monocytogenes BetL system into the probiotic strain Bifidobacterium breve UCC2003 significantly improved the tolerance of the strain to gastric juice and elevated osmolarity [59]. In addition, $\operatorname{BetL}^{+} B$. breve was recovered at much higher levels from the faeces, intestines and caecum of BetL ${ }^{+}$inoculated mice compared to control mice inoculated with the BetL' strain, and Listeriachallenge experiments revealed that $\mathrm{BetL}^{+}$mice exhibited reduced levels of Listeria infection in the spleen compared to controls [59].

The marked ability of L. monocytogenes to survive the stresses encountered in the upper small intestine has been linked to its capacity to endure high bile concentrations. Indeed, L. monocytogenes has been isolated from the human gallbladder [60,61]. A novel bile resistance mechanism, termed BilE was identified in $L$. monocytogenes and operates by excluding bile from the cell [62]. Heterologous expression of BilE in L. lactis NZ9800 and B. breve UCC2003 resulted in modified strains with enhanced capacities to survive in the presence of bile [63]. For example, the bilE-containing strain of $L$. lactis exhibited a $2.5 \mathrm{log}$ enhanced resistance (compared to control) following a 20 minute exposure to $1 \%$ porcine bile, a similar result was observed for the bilE-containing strain of $B$. breve. In addition, both genetically modified strains exhibited an enhanced ability to survive in vivo conditions using mouse models. This was particularly noteworthy for the bilE-containing L. lactis strain considering that it is generally not considered to be a gut inhabitant due to its poor survival rates in the GIT. Indeed, the $\mathrm{BilE}^{+} L$. lactis strain was detected at high levels in murine faeces 3 days after inoculation whereas the $\mathrm{BilE}^{-} L$. lactis strain was undetectable in the faecal samples on day 2 after inoculation. While both $\mathrm{BilE}^{+}$and BilE ${ }^{-}$strains of B. breve colonised 
the murine GI tract at relatively similar rates $\left(10^{7} \mathrm{cfu} / \mathrm{g}\right.$ of faeces), the persistence of the $\mathrm{BilE}^{+}$strain began to differ significantly 12 days after inoculation. Indeed, by day 19 the BilE $^{-}$strain had reached a level of $1 \times 10^{5}$ $\mathrm{cfu} / \mathrm{g}$ of faeces, whereas the $\mathrm{BilE}^{+}$strain persisted at a level of $4.5 \times 10^{7} \mathrm{cfu} / \mathrm{g}$ of faeces. Moreover, by day 19 the levels of the $\mathrm{BilE}^{+}$strain in the small intestine, caecum and large intestine were significantly higher compared to the control strain. This was a particularly important finding for the small intestine, a region of the GIT which has the highest levels of bile [64]. Indeed, the persistence levels of the genetically modified strain were 100 fold greater than the persistence levels of the control. The BilE ${ }^{+}$strain also enhanced clearance of $L$. monocytogenes from the liver at significant levels when compared to the control strain.

\section{Exploiting generic microbial mechanisms}

Improving probiotic robustness can also be achieved by looking to other microbial mechanisms which may not be necessarily associated with pathogenic survival. For example, various studies have demonstrated that probiotic robustness can be significantly enhanced by adding a protectant to the growth medium prior to exposure of the strain to environmental stress. An exudate gum from trees, gum acacia, enhanced survival of $L b$. paracasei NFBC 338 from the stresses of heat, bile and $\mathrm{H}_{2} \mathrm{O}_{2}$ when added to the growth medium and also enhanced survival during spray-drying [65]. We proposed that the protective effect of gum acacia may be related to cellular encapsulation by the polysaccharide thus protecting the cells from the harsh environmental conditions. Many microorganisms produce exopolysaccharides (EPS) which can be either excreted into the medium or form a capsule around the cell, the capsular polysaccharides (CPS). Recently, a positive correlation was observed between EPS production and resistance to bile salt and low $\mathrm{pH}$ stress in Bifidobacterium species isolated from breast milk and infant faeces [66]. Interestingly, both the technological and gastrointestinal durability of $L b$. paracasei NFBC 338 was significantly improved by equipping the strain with an inherent ability to produce the EPS beta-glucan [67]. The gene encoding this particular EPS, the membrane-associated glycosyltransferase enzyme ( $g t f)$ comes from Pediococcus parvulus 2.6. Indeed, heterologous expression of the gene in $L b$. paracase $i$ increased its heat tolerance 60 -fold, its acid-tolerance 20 -fold, its ability to survive in simulated gastric juice by 15 -fold and its ability to survive in bile by 5.5 fold, compared to the control strain (Figure 3). Moreover, betaglucan has been linked with many health-promoting properties including an ability to lower serum cholesterol levels [68,69], immunomodulation [70,71], anticancer properties [72] and it behaves as a prebiotic [73].
Thus, as well as enhancing the gastrointestinal robustness of the strain Stack et al., [67] simultaneously improved its health-promoting properties.

Other microbial mechanisms have also proven worthwhile as tools for probiotic enhancement. Heterologous expression of the manganese superoxide dismutase gene $(\operatorname{sod} A)$ from Streptococcus thermophilus in the intestinal strains Lactobacillus gasseri and Lb. acidophilus enabled the cells to tolerate greater concentrations of $\mathrm{H}_{2} \mathrm{O}_{2}$ (up to $1.6 \mathrm{mM}$ ) compared to the control which could not adequately tolerate concentrations greater than $1.2 \mathrm{mM}$ [74]. Integration of $\operatorname{sod} A$ into the chromosome of $L b$. gasseri also dramatically improved its oxidative tolerance, whereby the modified strain was capable of surviving up to $45 \mathrm{mM} \mathrm{H}_{2} \mathrm{O}_{2}$ after 90 minutes of exposure, unlike the control strain which was unable to tolerate concentrations greater than $25 \mathrm{mM}$ [75]. Moreover, cloning the catalase gene katA from Lb. sakei SR911 into catalase-deficient $L b$. planatarum TISTR850 under a strong lactococcal promoter improved the oxidative tolerance of the modified strain markedly [76]. Indeed, the modified strain survived 6 logs better than the control following 60 hours of growth under oxidative stress. Likewise, cloning katA from Lb. sakei into Lactobacillus rhamnosus AS 1.2466 significantly improved the oxidative resistance of the recombinant strain [77]. The exponential-phase culture of the modified strain increased 600-fold following $\mathrm{H}_{2} \mathrm{O}_{2}$ challenge and the stationaryphase culture increased 1000-fold under the same conditions when compared to the control. Endowing the probiotic strain Lactobacillus casei with both katA (from Lb. sakei) and the bile salt hydrolase gene bsh1 (from Lb. plantarum) dramatically enhanced both the oxidative tolerance and the bile salt resistance of the strain [78]. The survival ratio of the recombinant strain was 40 -fold greater than the control after 8 hours of incubation in the presence of $8 \mathrm{mM} \mathrm{H}_{2} \mathrm{O}_{2}$, while the recombinant strain survived in the presence of $0.5 \%$ glycodeoxycholate reaching $10^{5} \mathrm{cfu} / \mathrm{ml}$, a concentration which killed the control cells.

\section{New players involved in the probiotic stress response}

Proteomics and whole genome DNA microarrays alongside heterologous expression studies and the generation of deletion mutants continue to provide important insights into the response and adaptation of probiotic bacteria to environmental stresses. Indeed, studies which employ such techniques continually highlight the importance of the main molecular defense mechanisms, reveal stress-associated regulatory networks, but also provide insight into novel systems which serve to protect the stressed cell providing new molecular tools for probiotic enhancement. A global analysis of the transcriptomes of 

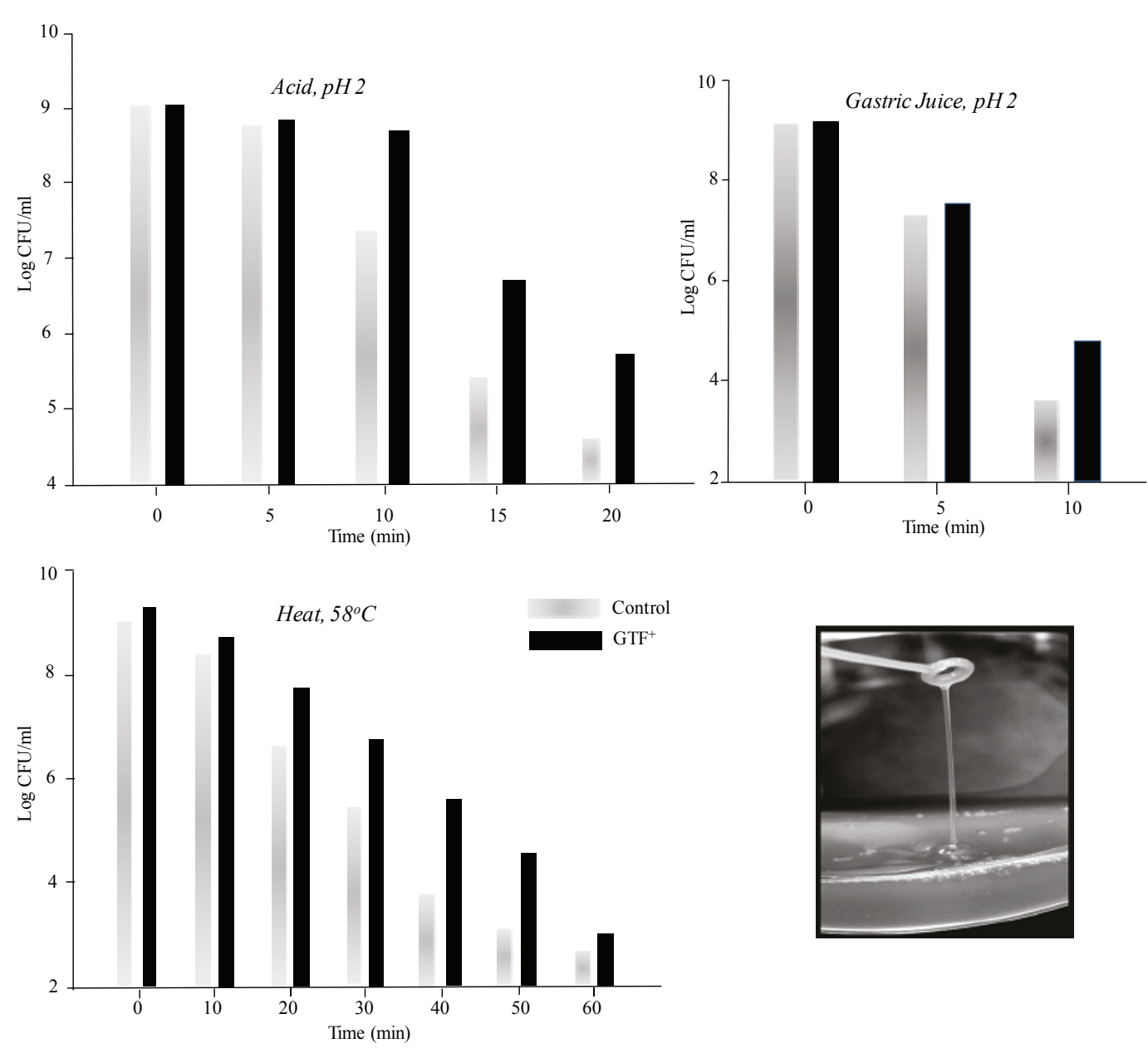

Figure 3 Survival of $L b$. paracasei NFBC 338 expressing the gtf gene $\left(G_{T F}^{+}\right)$and control strain in the presence of acid, gastric juice and elevated temperature. Inset displays the loop-touch test of $L b$. paracasei NFBC 338 producing EPS demonstrating the 'ropy' phenotype of the modified strain (adapted from Stack et al. [67]).

two heat-shock tolerant strains of B. longum (isolated following serial passages at heat-shock temperatures) demonstrated that overexpression of the dnaK operon and $\operatorname{clp} B$ protease-encoding gene was linked to point mutations in the gene encoding the negative regulator, HspR [79]. Indeed, in one mutant a tyrosine residue was replaced by a histidine in the helix-turn-helix domain of the regulator, while in the second mutant a tyrosine residue was replaced with a cysteine in the winged 1 motif of the protein. Sensitivity to heat was restored by complementing the mutant strains with the wild-type $h s p R$ gene. Interestingly, the arginine deiminase (ADI) pathway of Lactobacillus fermentum IMDO 130101, a strain isolated from sourdough, was shown to respond to salt and temperature stresses resulting in an increase in ornithine production [80]. The ADI pathway functions to produce extra ATP and aid with acid stress
[80]. The authors suggest that the main function of the ADI pathway at high temperature is to provide energy to stationary phase cells and improve energy generation for growing cells under osmotic stress.

Heterologous expression of myosin-cross reactive antigen (MCRA), from B. breve NCIMB 702258, in Lactococcus and Corynebacterium improved sensitivity of both recombinant strains to heat and solvent stresses suggesting that this FAD-dependent fatty acid hydratase is involved in protecting the cell from environmental stress [81]. In addition, deletion of MCRA in Lb. acidophilus NCFM resulted in reduced growth of the deletion mutant in the presence of acids, bile and salt and significantly reduced the ability of the mutant strain to adhere to Caco- 2 cells suggesting a role for the gene in the stress response, cell division and Caco-2 cell adherence [82]. Poly $\mathrm{P}$ granules are polyanionic inorganic biopolymers of 
orthophosphate residues which have been associated with stress responses in bacteria [83]. The putative polyphosphate kinase gene of Bifidobacterium scardovii responsible for poly $\mathrm{P}$ synthesis was recently linked to the oxidative stress response as well as providing protection against other environmental stresses such as low $\mathrm{pH}$ [83].

Highest survival of $L b$. casei ATCC 334 to acid stress was achieved by exposing the cells to $\mathrm{pH} 4.5$ for 10 or 20 minutes [84]. Whole genome DNA microarrays revealed the up-regulation of 104 genes and the downregulation of 216 genes after 20 minutes at $\mathrm{pH}$ 4.5. Malolactic fermentation and histidine accumulation were also revealed as important features of acid adaptation in Lb. casei. Malolactic enzyme was up-regulated 16-fold and 7 fold following 5 and 20 minutes of acid exposure, respectively. This enzyme functions to decarboxylate Lmalate to L-lactate and $\mathrm{CO}_{2}$, thus contributing to alkalinization of the cytoplasm and enabling the production of ATP through $\mathrm{H}^{+}$-ATPase $[85,86]$. The transcriptome of cells exposed to acid for 20 minutes also revealed the up-regulation of an eight gene cluster involved in histidine biosynthesis. The authors postulated that histidine accumulation may contribute to the buffering capacity within the cell and is the first report that histidine accumulation may enhance acid resistance in bacteria. Interestingly, addition of either $30 \mathrm{mM}$ histidine or $30 \mathrm{mM}$ malate during acid exposure $(\mathrm{pH} 2.5)$ for 60 minutes or 2 hours improved cell survival more than 100 -fold or more than $10^{7}$-fold, respectively. The activity of the LuxS-mediated quorum sensing system, which is responsible for generating the universal signaling molecule called autoinducer-2 (AI-2) was found to be significantly increased following exposure to acid shock in $L b$. acidophilus NCFM and Lb. rhamnosus GG suggesting a role for the $\operatorname{luxS}$ gene in the acid stress response of lactobacilli [87]. The gene encoding the universal stress protein Usp1 was also recently suggested to be an important mediator in the acid stress response of $L b$. plantarum [88]. Indeed, studies in Escherichia coli demonstrated that Usp1 from $L b$. plantarum inactivates the negative regulator PadR which is involved in the phenolic acid stress response by negatively regulating $\operatorname{pad} A$, a gene which encodes the phenolic acid decarboxylase enzyme.

A whole genome DNA microarray was employed to determine the transcriptional response of $L b$. reuteri ATCC 55730 to bile [89]. Differential expression of a wide variety of genes involved in cell envelope stress, protein denaturation and DNA damage was observed. Interestingly, survival of $L b$. reuteri in the presence of bile was decreased by mutating a $\mathrm{Clp}$ chaperone, a putative esterase and a gene of unknown function, whereas the ability of the strain to restart growth in the presence of bile was hampered by mutating two operon genes, a multidrug resistance (MDR) transporter and a gene of unknown function, suggesting their importance in the bile stress response. The importance of MDR transporters for the bile stress response of Lb. acidophilus was also revealed by Pfeiler and Klaenhammer [90]. Indeed, of the ten most highly induced genes in Lb. acidophilus in the presence of bile, two were found to encode MDR transporters. These transporters function by extruding structurally unrelated compounds from the cell including antibiotics and bile salts [90]. MDR transporters were also identified in B. longum and B. breve following exposure to sub-inhibitory concentrations of bile [91]. Expression of the MDR transporter from B. longum in $E$. coli conferred bile resistance on the heterologous host when exposed to $3 \%$ bile [91]. However, the modified strain exhibited a reduced growth rate; hence the authors suggest that production of the MDR transporter is toxic for the cells. A gene responsible for S-layer production in $L b$. acidophilus ATCC 4356, slpA, was found to be induced in bile concentrations ranging from 0.01$0.05 \%$ [92]. S-layer proteins are external bacterial structures which have been associated with protection against hostile environmental elements and the establishment of Lb. acidophilus in the GIT [93-95]. However, the expression of $\operatorname{slp} A$ in $0.1 \%$ bile was lower than that recorded in 0.02 and $0.05 \%$ bile although the level of Slayer protein on the cell surface increased in concentration. The authors therefore suggest that $\operatorname{sip} B$, rather than $\operatorname{slp} A$, may be expressed during unfavorable growth conditions [92]. A putative aggregation-promoting factor (Apf) of Lb. acidophilus NCFM has been linked to survival of the strain during passage through the GIT and may even be involved in bacterium-host interactions [96]. Indeed, a $\Delta a p f$ deletion mutant was much more susceptible to bile and detergent, and survival rates of the mutant strain were decreased in simulated gastric juice compared to the control. Moreover, adherence of stationary phase mutant cells to an intestinal epithelial cell line was reduced. Overall, the results of the study suggest that Apf-like proteins are important for the gastrointestinal robustness of $L b$. acidophilus.

\section{Holistic approaches to understanding and exploiting the probiotic stress response}

The general global cellular response of probiotic bacteria to environmental stresses can probably be grouped into six broad biological categories based on differential expression of the associated genes and on the encountered stress(es): (i) stress response genes, (ii) genes involved in energy metabolism, (iii) transcription and translation associated genes, (iv) genes involved in nucleotide metabolism and amino acid biosynthesis genes, (v) cell envelope and cell wall-associated genes, (vi) genes which have no assigned function. For 
example, whole genome DNA microarrays exploited to study the complete cellular response of $B$. longum $\mathrm{NCC} 2705$ to heat treatment of $50^{\circ} \mathrm{C}$ for 3,7 and 12 minutes revealed that genes involved in cell growth (ribosomal proteins, aminoacyl-tRNA synthetases, genes involved in cell division etc.) were markedly repressed, which as the authors suggest may represent a strategy to conserve energy which can then be directed towards protection mechanisms in the cell [97]. The most highly and rapidly induced genes included dnaK, grpE, dnaJ and the transcriptional repressor HspR. Genes encoding groEL and groES and the transcriptional regulator HrcA were induced but at lower levels. Numerous transcriptional regulators were induced which included 2 twocomponent response regulators and the corresponding sensor histidine kinases. Ten LacI-type sugar-responsive-repressors were up-regulated and genes involved in the SOS response were also induced including the transcriptional repressor LexA and genes encoding RecA, RecX and RecN as well as the trans-translation machinery. This latter mechanism involves a ribonucleoprotein complex made up of tmRNA (with properties of a tRNA and mRNA-encoded by $s s r A$ ) and the protein SmpB. Stalled translational complexes serve as the target for tmRNA-SmpB which 'rescues' the ribosome and tags the nascent polypeptide and mRNAs for degradation [98]. While $s s r A$ was constitutively expressed, the gene encoding SmpB was highly induced following heat-treatment in B. longum.

An investigation into the global stress response of $B$. breve UCC2003 to moderate and severe heat treatment as well as osmotic, solvent and oxidative stress revealed that an interactive regulatory network controls the stress response in this strain $[99,100]$. Interestingly, exposure to moderate temperatures of $42^{\circ} \mathrm{C}$ and $44^{\circ} \mathrm{C}$ for 1 hour resulted in the induction of 5 and 17 genes, respectively and down-regulation of 11 and 92 genes, respectively. In contrast, 267 genes were induced during severe heat treatment $\left(47^{\circ} \mathrm{C}\right)$ while 266 genes were down-regulated. Under conditions of severe heat shock, genes belonging to carbohydrate transport and metabolism, energy production and conversion and nucleotide transport and metabolism were negatively regulated. Of the up-regulated genes only a fraction were involved in protein misfolding and DNA damage. Based on the overall results, the authors proposed a model interactive regulatory gene network for the bifidobacterial stress response whereby the negative regulator HspR controls the SOS response and the $\mathrm{ClgR}$ regulon, which in turn is regulated by and regulates the negative regulator HrcA $[99,100]$.

Previous studies have suggested that different bifidobacteria use NADH peroxidase to prevent the accumulation of $\mathrm{H}_{2} \mathrm{O}_{2}(101,102,103)$, however, none of the sequenced genomes to date contain gene analogs for this enzyme. Interestingly, a recent proteomic study of the oxidative stress-related responses of $B$. longum BBMN68 revealed a change in the expression of 51 protein spots following oxygen exposure revealing a distinctively different set of detoxification proteins compared to other anaerobes (104). Proteins involved in protecting proteins, DNA and RNA were identified including alkyl hydroperoxide reductase (AhpC), pyridine nucleotidedisulfide reductase (PNDR), and DNA oxidative damage-protective proteins including DNA-binding ferritin-like protein (Dps), ribonucleotide reductase (NrdA) and NTP phosphohydrolases (Mut1). The activity of Dps in oxidative stress protection was confirmed by in vitro and in vivo studies. Indeed, in vitro studies revealed that Dps binds DNA to protect it from oxidative degradation and over-expression of the protein in $E$. coli increased survival of the cells under oxidative challenge.

Adapting Lb. casei ATCC 334 to a broad range of acid stresses to improve the acid tolerance of the strain demonstrated that exposure to $\mathrm{pH} 4.5$ for 10 or $20 \mathrm{~min}$ utes resulted in the highest survival [84]. Assessment of the transcriptional responses of the strain following 5 and 20 minutes of exposure to this $\mathrm{pH}$ revealed a dramatic increase in the number of responsive genes following the 20 minute treatment (320 genes with altered expression levels). The majority of genes were downregulated. This was particularly apparent for genes involved in information storage and processing including translation, ribosomal structure and biogenesis, transcription, DNA replication, recombination and repair as well as genes involved in cellular processes such as protein turnover and remarkably stress response genes and those involved in cell secretion and cell envelope biogenesis. Up-regulated genes included the malolactic enzyme (as discussed earlier) and genes involved in amino acid transport and metabolism, including those involved in the transport of histidine as previously discussed. Interestingly, genes involved in the mobile DNA elements category were also up-regulated following acid adaptation for 20 minutes. Of the poorly characterized up-regulated genes, three were associated with phospholipid turnover: an acetyl transferase, an esterase, and a putative membrane-associated phospholipid phosphatase. Acid-adapted cells had higher total percentages of saturated and cyclopropane fatty acids in the cytoplasmic membrane than control cells which may be linked to the up-regulation of the three phospholipid-associated genes. Other studies have also demonstrated that acid stress induces changes in the cytoplasmic membrane fatty acid content in Lactobacillus[105,106]. Moreover, several stresses have been shown to cause an increase in the concentration of cyclopropane fatty acids 
in the cell membrane including heat stress [107], osmotic stress [108], and bile stress [109,110]. Indeed, using both transcriptomics and strategic proteomics approaches which also enabled a study of cell surface properties (surfome) Koskenniemi et al., [109] demonstrated the up-regulation of a gene encoding cyclopropane-fatty-acyl-phospholipid synthase in Lb. rhamnosus GG in response to bile stress, although the level of upregulation was not deemed to be statistically significant. This study also demonstrated that bile shock resulted in the repression of EPS-encoding genes. The authors postulated that EPS serves to protect Lb. rhamnosus GG cells from the harsh environmental conditions of the stomach. However, the presence of bile serves as a signal of gut entrance and hence down-regulation in EPS production to enable better adherence of the bacterium to intestinal cells. Genes involved in the D-alanylation of the negatively charged lipotechoic acids were also upregulated in response to bile stress which was also observed for Lb. plantarum[111]. Such a strategy serves to increase the positive surface charge, and as the authors suggest possibly serves to repulse the cationic compounds in bile. Indeed, alteration of surface charge has also been associated with resistance to cationic peptides $[112,113]$ and we recently observed the same phenomenon in response to bacteriophage challenge in $L$. lactis (unpublished). Several two-component systems, multi-drug transporters, the $\mathrm{F}_{1} \mathrm{~F}_{0}$ - ATP synthase and a bile salt hydrolase were also up-regulated in response to bile stress as well as several chaperones and proteases directly involved in the stress response.

\section{Discussion}

The ability of probiotic bacteria to survive the harsh environments encountered during processing and gastrointestinal transit has been a major factor in their selection criteria. Indeed, induction of the probiotic stress response through pre-adaptation strategies may not always ensure the improved performance of a strain in compromising environments. For example, exposing B. longum DJO10A to sub-lethal stresses of acid, cold and centrifugation before addition to Cheddar cheese as a starter adjunct did not influence the viability of the culture during Cheddar cheese ripening [114]. Moreover, exposure of $L b$. acidophilus La-5, Lb. rhamnosus GG and Lb. fermentum ME-3 to temperature, acid or bile stress did not positively affect survival of the strains in a gastrointestinal tract simulator, with a marked decrease in cell numbers for all three strains after the bile phase [115]. In addition, the biological efficacy of probiotic cells may be compromised following exposure to stress. Indeed, spray drying was recently shown to negatively influence the adhesion capacity of Lactobacillus kefir 8348 but not Lb. plantarum 83114 or Lb. kefir 8321 to intestinal cells [116].
Developing a molecular toolbox, whether through pathobiotechnology, targeting indigenous defense strategies of lactic acid bacteria or indeed other bacterial groups, should ensure that the most biologically/functionally active strains can be confidently selected for probiotic development. Indeed, we have already seen how probiotic robustness can be dramatically improved by targeting even a single mechanism. By targeting several cellular defense mechanisms in one strain we should be able to develop designer organisms with the capacity to overcome the plethora of stresses presented during processing and in vivo survival.

However, despite the advantages of using such approaches this field of science is not without its limitations. Probiotics which have been enhanced in this way are genetically modified organisms and with the exception of the United States and Canada, there is still uncertainty in the public arena towards the use of genetic manipulation. Moreover, the use of pathogen derived genes in genetically modified probiotics through patho-biotechnology is a concept that undoubtedly consumer and regulatory groups may find hard to accept. Yet despite this, designer probiotics offer huge potential for both technological and clinical applications. For example, Sleator and Hill [117] suggest that 'bioengineered probiotics' may provide a safer alternative to attenuated pathogens which are currently used as vaccine delivery platforms or may be used as novel drug delivery vehicles. Moreover, one of the major obstacles associated with genetic manipulation to date is that the benefits of the technology rarely benefit the consumer but rather serve to maximize corporate profit. Genetically modified probiotics, on the other hand, should directly benefit the consumer. However, studies which evaluate the safety of engineered probiotics are crucial if the technology is to gain acceptance. For this reason continued investigation and understanding of the bacterial stress response is a highly worthwhile endeavor in probiotic science providing strategies for scientists to manipulate probiotics to their full potential. In this way next-generation probiotic cultures will be better equipped to face technological and gastrointestinal challenges, (which at the moment can be a rate-limiting step in probiotic selection) as well as meeting medical demands.

\section{Acknowledgements}

This article has been published as part of Microbial Cell Factories Volume 10 Supplement 1, 2011: Proceedings of the 10th Symposium on Lactic Acid Bacterium. The full contents of the supplement are available online at http:// www.microbialcellfactories.com/supplements/10/S1.

\section{Author details}

'Teagasc Food Research Centre, Moorepark, Fermoy, Co. Cork, Ireland.

${ }^{2}$ Department of Microbiology, University College Cork, Ireland. ${ }^{3}$ Alimentary

Pharmabiotic Centre, Cork, Ireland. 


\section{Competing interests}

The authors declare that they have no competing interests.

Published: 30 August 2011

\section{References}

1. Global Industry Analysts Inc: Probiotics: A Global Strategic Business Report. 2010 [http://www.researchandmarkets.com].

2. Mills S, Stanton C, Ross RP: Microbial production of bioactives: from fermented Functional Foods to probiotic mechanisms. Austral. J. Dairy Technol 2009, 64:41-49.

3. O'Flaherty S, Saulnier DM, Pot B, Versalovic J: How can probiotics and prebiotics impact mucosal immunity? Gut Microbes 2010, 1:293-300.

4. Ross RP, Mills S, Hill C, Fitzgerald GF, Stanton C: Specific metabolite production by gut microbiota as a basis for probiotic function. Int Dairy $\mathrm{J}$ 2010, 20:269-276.

5. Corcoran BM, Ross RP, Fitzgerald GF, Dockery P, Stanton C: Enhanced survival of GroESL-overproducing Lactobacillus paracasei NFBC 338 under stressful conditions induced by drying. Appl Environ Microbiol 2006 , 72:5104-5107.

6. Guinane CM, Kent RM, Norberg S, Hill C, Fitzgerald GF, Stanton C, Ross RP. Host specific diversity in Lactobacillus johnsonii as evidenced by a major chromosomal inversion and phage resistance mechanisms. Plos One 2011, 6:e18740.

7. Muller JA, Ross RP, Sybesma WFH, Fitzgerald GF, Stanton C: Modification of technical properties of Lactobacillus johnsonnii NCC 533 by supplementing growth medium with unsaturated fatty acids. App/ Environ Microbiol 2011, doi:10.1128/AEM.05213-11.

8. Meng XC, Stanton C, Fitzgerald GF, Daly C, Ross RP: Anhydrobiotics: the challenges of drying probiotic cultures. Food Chemistry 2008, 106:1406-1416.

9. Somero GN: Proteins and temperature. Annu Rev Physiol 1995, 57:43-68

10. Teixeira P, Castro H, Mohacsi-Farkas C, Kirby R: Identification of sites of injury in Lactobacillus bulgaricus during heat stress. J Appl Microbiol 1997, 83:219-226.

11. Santivarangkna C, Kulozik U, Foerst P: Alternative drying processes for the industrial preservation of lactic acid starter cultures. Biotechnol Prog 2007, 23:302-315.

12. Jennings TA: Lyophilisation - introduction and basic principles. Boca Raton: CRC Press; 1999

13. Oetjen GW: Freeze-drying. Weinheim: Wiley-VCH; 1999.

14. Wang YC, Yu RC, Chou CC: Viability of lactic acid bacteria and bifidobacteria in fermented soymilk after drying, subsequent rehydration and storage. Int J Food Microbiol 2004, 93:209-217.

15. van de Guchte M, Serror P, Chervaux C, Smokvina T, Ehrlich SD, Maguin E: Stress responses in lactic acid bacteria. Antonie Van Leeuwenhoek; 2002:82:187-216.

16. Bayles DO, Tunick MH, Foglia TA, Miller AJ: Cold shock and its effect on ribosomes and thermal tolerance in Listeria monocytogenes. Appl Environ Microbiol 2000, 66:4351-4355.

17. Graumann PL, Marahiel MA: Cold shock response in Bacillus subtilis. J Mol Microbiol Biotechnol 1999, 1:203-209.

18. Miyoshi A, Rochat T, Gratadoux JJ, Le Loir Y, Oliveira SC, Langella P, Azevedo V: Oxidative stress in Lactococcus lactis. Genet Mol Res 2003, 2:348-359.

19. Vido K, Diemer H, Van Dorsselaer A, Leize E, Juillard V, Gruss A, Gaudu P: Roles of thioredoxin reductase during the aerobic life of Lactococcus lactis. J Bacteriol 2005, 187:601-610.

20. Lee JH, O'Sullivan DJ: Genomic insights into bifidobacteria. Microbiol Mol Biol Rev 2010, 74:378-416.

21. Cronin M, Ventura M, Fitzgerald GF, van Sinderen D: Progress in genomics, metabolism and biotechnology of bifidobacteria. Int J Food Microbiol 2011, 149:4-18.

22. Simpson PJ, Ross RP, Fitzgerald GF, Stanton C: Bifidobacterium psychraerophilum sp. nov. and Aeriscardovia aeriphila gen. nov., sp. nov., isolated from a porcine caecum. Int I Syst Evol Microbiol 2004, 54:401-406.

23. Bolduc MP, Raymond Y, Fustier $P$, Champagne CP, Vuillemard JC: Sensitivity of bifidobacteria to oxygen and redox potential in non-fermented pasteurised milk. Int Dairy J 2006, 16:1038-1048.

24. Odamaki T, Xiao JZ, Yonezawa S, Yaeshima T, Iwatsuki K: Improved viability of bifidobacteria in fermented milk by cocultivation with Lactococcus lactis subspecies lactis. J Dairy Sci 2011, 94:1112-1121.
25. Hufner E, Markieton T, Chaillou S, Crutz-Le Coq AM, Zagorec M, Hertel C: Identification of Lactobacillus sakei genes induced during meat fermentation and their role in survival and growth. Appl Environ Microbiol 2007, 73:2522-2531.

26. Hufner E, Britton RA, Roos S, Jonsson H, Hertel C: Global transcriptional response of Lactobacillus reuteri to the sourdough environment. Syst Appl Microbiol 2008, 31:323-338.

27. Fortin $\mathrm{MH}$, Champagne $\mathrm{CP}$, St-Gelais $\mathrm{D}$, Britten M, Fustier $\mathrm{P}$, Lacroix M: Effect of time of inoculation, starter addition, oxygen level and salting on the viability of probiotic cultures during Cheddar cheese manufacture. Int Dairy J 2011, 21:75-82.

28. Leverrier P, Fremont $Y$, Rouault A, Boyaval P, Jan G: In vitro tolerance to digestive stresses of propionibacteria: influence of food matrices. Food Microbiol 2005, 22:11-18.

29. Corcoran BM, Stanton C, Fitzgerald G, Ross RP: Life under stress: the probiotic stress response and how it may be manipulated. Curr Pharm Des 2008, 14:1382-1399.

30. Begley M, Gahan CG, Hill C: The interaction between bacteria and bile. FEMS Microbiol Rev 2005, 29:625-651.

31. Leverrier P, Dimova D, Pichereau V, Auffray Y, Boyaval P, Jan G: Susceptibility and adaptive response to bile salts in Propionibacterium freudenreichii: physiological and proteomic analysis. Appl Environ Microbiol 2003, 69:3809-3818.

32. De Angelis M, Gobbetti M: Environmental stress responses in Lactobacillus: a review. Proteomics 2004, 4:106-122.

33. Sugimoto $\mathrm{S}$, Abdullah Al M, Sonomoto K: Molecular chaperones in lactic acid bacteria: physiological consequences and biochemical properties. J Biosci Bioeng 2008, 106:324-336.

34. van Schaik W, Abee T: The role of $\sigma B$ in the stress response of Grampositive bacteria - targets for food preservation and safety. Curr Opin Biotechnol 2005, 16:218-224.

35. Klaenhammer TR, Altermann E, Azcarate-Peril MA, McAuliffe O, Russell M: Lactobacillus acidophilus nucleic acid sequences encoding stress-related proteins and uses thereof. 2010, Patent No. WO/2005/086794 (USA).

36. Desmond C, Stanton C, Fitzgerald GF, Collins K, Ross RP: Environmental adaptation of probiotic lactobacilli towards improvement of performance during spray drying. Int Dairy J 2001, 11:801-808.

37. Desmond C, Fitzgerald GF, Stanton C, Ross RP: Improved stress tolerance of GroESL-overproducing Lactococcus lactis and probiotic Lactobacillus paracasei NFBC 338. Appl Environ Microbiol 2004, 70:5929-5936.

38. Jakob U, Gaestel M, Engel K, Buchner J: Small heat shock proteins are molecular chaperones. J Biol Chem 1993, 268:1517-1520.

39. Narberhaus F: Alpha-crystallin-type heat shock proteins: socializing minichaperones in the context of a multichaperone network. Microbiol Mol Biol Rev 2002, 66:64-93.

40. Veinger L, Diamant S, Buchner J, Goloubinoff P: The small heat-shock protein IbpB from Escherichia coli stabilizes stress-denatured proteins for subsequent refolding by a multichaperone network. J Biol Chem 1998, 273:11032-11037.

41. Spano G, Capozzi V, Vernile A, Massa S: Cloning, molecular characterization and expression analysis of two small heat shock genes isolated from wine Lactobacillus plantarum. J Appl Microbiol 2004, 97:774-782.

42. Spano G, Beneduce L, Perrotta C, Massa S: Cloning and characterization of the hsp 18.55 gene, a new member of the small heat shock gene family isolated from wine Lactobacillus plantarum. Res Microbiol 2005, $156: 219-224$

43. Capozzi V, Weidmann S, Fiocco D, Rieu A, Hols P, Guzzo J, Spano G: Inactivation of a small heat shock protein affects cell morphology and membrane fluidity in Lactobacillus plantarum WCFS1. Res Microbiol 2011

44. Fiocco D, Capozzi V, Goffin P, Hols P, Spano G: Improved adaptation to heat, cold, and solvent tolerance in Lactobacillus plantarum. Appl Microbiol Biotechnol 2007, 77:909-915.

45. Phadtare S, Inouye M: Role of CspC and CspE in regulation of expression of RpoS and UspA, the stress response proteins in Escherichia coli. J Bacteriol 2001, 183:1205-1214

46. Derzelle S, Hallet B, Francis KP, Ferain T, Delcour J, Hols P: Changes in cspL, $\operatorname{csp} P$, and $\operatorname{csp} C$ mRNA abundance as a function of cold shock and growth phase in Lactobacillus plantarum. J Bacteriol 2000, 182:5105-5113.

47. Derzelle S, Hallet B, Ferain T, Delcour J, Hols P: Improved adaptation to cold-shock, stationary-phase, and freezing stresses in Lactobacillus 
plantarum overproducing cold-shock proteins. Appl Environ Microbiol 2003, 69:4285-4290.

48. Sleator RD, Hill C: Patho-biotechnology: using bad bugs to do good things. Curr Opin Biotechnol 2006, 17:211-216.

49. Sleator RD, Hill C: Bacterial osmoadaptation: the role of osmolytes in bacterial stress and virulence. FEMS Microbiol Rev 2001, 26:49-71.

50. Galinski EA: Osmoadaptation in bacteria. Adv Microb Physiol 1995, 37:272-328.

51. Brown AD: Microbial water stress. Bacteriol Rev 1976, 40:803-846

52. Lippert K, Galinski EA: Enzyme stabilisation by ectoine-type compatible solutes: protection against heating, freezing and drying. Appl Microbiol Biotechnol 1992, 37:61-65.

53. Welsh DT: Ecological significance of compatible solute accumulation by micro-organisms: from single cells to global climate. FEMS Microbiol Rev 2000, 24:263-290.

54. Sheehan VM, Sleator RD, Fitzgerald GF, Hill C: Heterologous expression of BetL, a betaine uptake system, enhances the stress tolerance of Lactobacillus salivarius UCC118. Appl Environ Microbiol 2006, 72:2170-2177.

55. Sleator RD, Francis GA., O'Beirne D, Gahan CG, Hill C: Betaine and carnitine uptake systems in Listeria monocytogenes affect growth and survival in foods and during infection. J Appl Microbiol 2003, 95:839-846.

56. Sleator RD, Gahan CG, Abee T, Hill C: Identification and disruption of BetL, a secondary glycine betaine transport system linked to the salt tolerance of Listeria monocytogenes LO28. Appl Environ Microbiol 1999, 65:2078-2083.

57. Sleator RD, Gahan CG, Hill C: A postgenomic appraisal of osmotolerance in Listeria monocytogenes. Appl Environ Microbiol 2003, 69:1-9.

58. Smiddy M, Sleator RD, Patterson MF, Hill C, Kelly AL: Role for compatible solutes glycine betaine and L-carnitine in listerial barotolerance. Appl Environ Microbiol 2004, 70:7555-7557.

59. Sheehan VM, Sleator RD, Hill C, Fitzgerald GF: Improving gastric transit, gastrointestinal persistence and therapeutic efficacy of the probiotic strain Bifidobacterium breve UCC2003. Microbiology 2007, 153:3563-3571.

60. Briones V, Blanco MM, Marco A, Prats N, Fernandez-Garayzabal JF, Suarez G, Domingo $\mathrm{M}$, Dominguez L: Biliary excretion as possible origin of Listeria monocytogenes in fecal carriers. Am J Vet Res 1992, 53:191-193.

61. Hardy J, Francis KP, DeBoer M, Chu P, Gibbs K, Contag CH: Extracellular replication of Listeria monocytogenes in the murine gall bladder. Science 2004, 303:851-853.

62. Sleator RD, Wemekamp-Kamphuis HH, Gahan CG, Abee T, Hill C: A PrfAregulated bile exclusion system (BilE) is a novel virulence factor in Listeria monocytogenes. Mol Microbiol 2005, 55:1183-1195.

63. Watson D, Sleator RD, Hill C, Gahan CG: Enhancing bile tolerance improves survival and persistence of Bifidobacterium and Lactococcus in the murine gastrointestinal tract. BMC Microbiol 2008, 8:176.

64. Begley M, Sleator RD, Gahan CG, Hill C: Contribution of three bileassociated loci, bsh, pva, and $b t \mid B$, to gastrointestinal persistence and bile tolerance of Listeria monocytogenes. Infect Immun 2005, 73:894-904.

65. Desmond C, Ross RP, O'Callaghan E, Fitzgerald G, Stanton C: Improved survival of Lactobacillus paracasei NFBC 338 in spray-dried powders containing gum acacia. J Appl Microbiol 2002, 93:1003-1011.

66. Alp G, Aslim B: Relationship between the resistance to bile salts and low $\mathrm{pH}$ with exopolysaccharide (EPS) production of Bifidobacterium spp. isolated from infants feces and breast milk. Anaerobe 2010, 16:101-105.

67. Stack HM, Kearney N, Stanton C, Fitzgerald GF, Ross RP: Association of beta-glucan endogenous production with increased stress tolerance of intestinal lactobacilli. Appl Environ Microbiol 2010, 76:500-507.

68. Theuwissen E, Mensink RP: Water-soluble dietary fibers and cardiovascular disease. Physiol Behav 2008, 94:285-292.

69. Wilson TA, Nicolosi RJ, Delaney B, et al: Reduced and high molecular weight barley beta-glucans decrease plasma total and non-HDL-cholesterol in hypercholesterolemic Syrian golden hamsters. J Nutr 2004, 134:2617-2622.

70. Akramiene D, Kondrotas A, Didziapetriene J, Kevelaitis E: Effects of betaglucans on the immune system. Medicina (Kaunas) 2007, 43:597-606.

71. Volman JJ, Ramakers JD, Plat J: Dietary modulation of immune function by beta-glucans. Physiol Behav 2008, 94:276-284.

72. Mantovani MS, Bellini MF, Angeli JP, Oliveira RJ, Silva AF, Ribeiro LR: betaGlucans in promoting health: prevention against mutation and cancer. Mutat Res 2008, 658:154-161.

73. Snart J, Bibiloni R, Grayson T, et al: Supplementation of the diet with highviscosity beta-glucan results in enrichment for lactobacilli in the rat cecum. Appl Environ Microbiol 2006, 72:1925-1931.
74. Bruno-Barcena JM, Andrus JM, Libby SL, Klaenhammer TR, Hassan HM: Expression of a heterologous manganese superoxide dismutase gene in intestinal lactobacilli provides protection against hydrogen peroxide toxicity. Appl Environ Microbiol 2004, 70:4702-4710.

75. Bruno-Barcena JM, Azcarate-Peril MA, Klaenhammer TR, Hassan HM: Markerfree chromosomal integration of the manganese superoxide dismutase gene (sodA) from Streptococcus thermophilus into Lactobacillus gasseri. FEMS Microbiol Lett 2005, 246:91-101.

76. Noonpakdee W, Sitthimonchai S, Panyim S, Lertsiri S: Expression of the catalase gene katA in starter culture Lactobacillus plantarum TISTR850 tolerates oxidative stress and reduces lipid oxidation in fermented meat product. Int J Food Microbiol 2004, 95:127-135.

77. An H, Zhou H, Huang Y, Wang G, Luan C, Mou J, Luo Y, Hao Y: High-level expression of heme-dependent catalase gene katA from Lactobacillus sakei protects Lactobacillus rhamnosus from oxidative stress. Mol Biotechnol 2010, 45:155-160.

78. Wang G, Yin S, An H, Chen S, Hao Y: Coexpression of bile salt hydrolase gene and catalase gene remarkably improves oxidative stress and bile salt resistance in Lactobacillus casei. J Ind Microbiol Biotechnol 2010.

79. Berger $B$, Moine D, Mansourian R, Arigoni F: HspR mutations are naturally selected in Bifidobacterium longum when successive heat shock treatments are applied. J Bacteriol 2010, 192:256-263.

80. Vrancken G, Rimaux T, Wouters D, Leroy F, De Vuyst L: The arginine deiminase pathway of Lactobacillus fermentum IMDO 130101 responds to growth under stress conditions of both temperature and salt. Food Microbiol 2009, 26:720-727.

81. Rosberg-Cody E, Liavonchanka A, Gobel C, Ross RP, O'Sullivan O, Fitzgerald GF, Feussner I, Stanton C: Myosin-cross-reactive antigen (MCRA) protein from Bifidobacterium breve is a FAD-dependent fatty acid hydratase which has a function in stress protection. BMC Biochem 2011, 12:9.

82. O'Flaherty SJ, Klaenhammer TR: Functional and phenotypic characterization of a protein from Lactobacillus acidophilus involved in cell morphology, stress tolerance and adherence to intestinal cells. Microbiology 2010, 156:3360-3367.

83. Qian Y, Borowski WJ, Calhoon WD: Intracellular granule formation in response to oxidative stress in Bifidobacterium. Int J Food Microbiol 2011, 145:320-325

84. Broadbent JR, Larsen RL, Deibel V, Steele JL: Physiological and transcriptional response of Lactobacillus casei ATCC 334 to acid stress. J Bacteriol 2010, 192:2445-2458.

85. Poolman B, Molenaar D, Smid EJ, Ubbink T, Abee T, Renault PP, Konings WN: Malolactic fermentation: electrogenic malate uptake and malate/lactate antiport generate metabolic energy. J Bacteriol 1991, 173:6030-6037

86. Renault $\mathrm{P}$, Gaillardin $\mathrm{C}$, Heslot $\mathrm{H}$ : Role of malolactic fermentation in lactic acid bacteria. Biochimie 1988, 70:375-379.

87. Moslehi-Jenabian S, Gori K, Jespersen L: Al-2 signalling is induced by acidic shock in probiotic strains of Lactobacillus spp. Int J Food Microbiol 2009, 135:295-302.

88. Gury J, Seraut H, Tran NP, Barthelmebs L, Weidmann S, Gervais P, Cavin JF: Inactivation of PadR, the repressor of the phenolic acid stress response, by molecular interaction with Usp1, a universal stress protein from Lactobacillus plantarum, in Escherichia coli. Appl Environ Microbiol 2009, 75:5273-5283.

89. Whitehead K, Versalovic J, Roos S, Britton RA: Genomic and genetic characterization of the bile stress response of probiotic Lactobacillus reuteri ATCC 55730. Appl Environ Microbiol 2008, 74:1812-1819.

90. Pfeiler EA, Klaenhammer TR: Role of transporter proteins in bile tolerance of Lactobacillus acidophilus. Appl Environ Microbiol 2009, 75:6013-6016.

91. Gueimonde M, Garrigues C, van Sinderen D, de los Reyes-Gavilan CG, Margolles A: Bile-inducible efflux transporter from Bifidobacterium longum NCC2705, conferring bile resistance. Appl Environ Microbiol 2009, 75:3153-3160.

92. Khaleghi M, Kermanshahi RK, Yaghoobi MM, Zarkesh-Esfahani SH, Baghizadeh A: Assessment of bile salt effects on s-layer production, slp gene expression and some physicochemical properties of Lactobacillus acidophilus ATCC 4356. J Microbiol Biotechnol 2010, 20:749-756.

93. Avall-Jaaskelainen S, Palva A: Lactobacillus surface layers and their applications. FEMS Microbiol Rev 2005, 29:511-529.

94. Frece J, Kos B, Svetec IK, Zgaga Z, Mrsa V, Suskovic J: Importance of S-layer proteins in probiotic activity of Lactobacillus acidophilus M92. J Appl Microbiol 2005, 98:285-292. 
95. Kos B, Suskovic J, Vukovic S, Simpraga M, Frece J, Matosic S: Adhesion and aggregation ability of probiotic strain Lactobacillus acidophilus M92. J Appl Microbiol 2003, 94:981-987.

96. Goh YJ, Klaenhammer TR: Functional roles of aggregation-promoting-like factor in stress tolerance and adherence of Lactobacillus acidophilus NCFM. Appl Environ Microbiol 2010, 76:5005-5012.

97. Rezzonico E, Lariani S, Barretto C, Cuanoud G, Giliberti G, Delley M, Arigoni F, Pessi G: Global transcriptome analysis of the heat shock response of Bifidobacterium longum. FEMS Microbiol Lett 2007, 271:136-145

98. Keiler KC: Biology of trans-translation. Annu Rev Microbiol 2008, 62:133-151.

99. Zomer A, Fernandez M, Kearney B, Fitzgerald GF, Ventura M, van Sinderen D: An interactive regulatory network controls stress response in Bifidobacterium breve UCC2003. J Bacteriol 2009, 191:7039-7049.

100. Zomer A, van Sinderen D: Intertwinement of stress response regulons in Bifidobacterium breve UCC2003. Gut Microbes 2010, 1:100-102.

101. Shimamura S, Abe F, Ishibashi N, Miyakawa H, Yaeshima T, Araya T, Tomita M: Relationship between oxygen sensitivity and oxygen metabolism of Bifidobacterium species. J Dairy Sci 1992, 75:3296-3306.

102. Shin SY, Park JH: Activities of oxidative enzymes related with oxygen tolerance in Bifidobacterium sp. J Microbiol Biotechnol 1997, 7:356-359.

103. Talwalkar A, Kailasapathy K: Metabolic and biochemical responses of probiotic bacteria to oxygen. J Dairy Sci 2003, 86:2537-2546.

104. Xiao M, Xu P, Zhao J, Wang Z, Zuo F, Zhang J, Ren F, Li P, Chen S, Ma H: Oxidative stress-related responses of Bifidobacterium longum subsp. longum BBMN68 at the proteomic level after exposure to oxygen. Microbiology 2011, 157:1573-1588.

105. Montanari C, Sado Kamdem SL, Serrazanetti DI, Etoa FX, Guerzoni ME: Synthesis of cyclopropane fatty acids in Lactobacillus helveticus and Lactobacillus sanfranciscensis and their cellular fatty acids changes following short term acid and cold stresses. Food Microbiol 2010, 27:493-502.

106. Streit F, Delettre J, Corrieu G, Beal C: Acid adaptation of Lactobacillus delbrueckii subsp. bulgaricus induces physiological responses at membrane and cytosolic levels that improves cryotolerance. J Appl Microbiol 2008, 105:1071-1080.

107. Broadbent J.R, Lin C: Effect of heat shock or cold shock treatment on the resistance of Lactococcus lactis to freezing and lyophilization. Cryobiology 1999, 39:88-102.

108. Guillot A, Obis D, Mistou MY: Fatty acid membrane composition and activation of glycine-betaine transport in Lactococcus lactis subjected to osmotic stress. Int J Food Microbiol 2000, 55:47-51.

109. Koskenniemi K, Laakso K, Koponen J, et al: Proteomics and transcriptomics characterization of bile stress response in probiotic Lactobacillus rhamnosus GG. Mol Cell Proteomics 2011, 10-M110 002741.

110. Taranto MP, Fernandez Murga ML, Lorca G, de Valdez GF: Bile salts and cholesterol induce changes in the lipid cell membrane of Lactobacillus reuteri. J Appl Microbiol 2003, 95:86-91.

111. Bron PA, Molenaar D, de Vos WM, Kleerebezem M: DNA micro-array-based identification of bile-responsive genes in Lactobacillus plantarum. J Appl Microbiol 2006, 100:728-738.

112. Kovacs M, Halfmann A, Fedtke I, Heintz M, Peschel A, Vollmer W, Hakenbeck R, Bruckner R: A functional dlt operon, encoding proteins required for incorporation of $d$-alanine in teichoic acids in gram-positive bacteria, confers resistance to cationic antimicrobial peptides in Streptococcus pneumoniae. J Bacteriol 2006, 188:5797-5805.

113. Peschel A, Otto M, Jack RW, Kalbacher H, Jung G, Gotz F: Inactivation of the dlt operon in Staphylococcus aureus confers sensitivity to defensins, protegrins, and other antimicrobial peptides. J Biol Chem 1999, 274:8405-8410.

114. Scheller M, O'Sullivan DJ: Comparative analysis of an intestinal strain of Bifidobacterium longum and a strain of Bifidobacterium animalis subspecies lactis in Cheddar cheese. J Dairy Sci 2011, 94:1122-1131.

115. Sumeri I, Arike L, Stekolstsikova J, Uusna R, Adamberg S, Adamberg K, Paalme T: Effect of stress pretreatment on survival of probiotic bacteria in gastrointestinal tract simulator. Appl Microbiol Biotechnol 2010, 86:1925-1931.

116. Golowczyc MA, Silva J, Teixeira P, De Antoni GL, Abraham AG: Cellular injuries of spray-dried Lactobacillus spp. isolated from kefir and their impact on probiotic properties. Int J Food Microbiol 2011, 144:556-560.

117. Sleator RD, Hill C: Bioengineered bugs - a patho-biotechnology approach to probiotic research and applications. . Med Hypotheses 2008, 70:167-169.

118. Prasad J, McJarrow P, Gopal P: Heat and osmotic stress responses of probiotic Lactobacillus rhamnosus HN001 (DR20) in relation to viability after drying. Appl Environ Microbiol 2003, 69:917-925.

119. Suokko A, Savijoki K, Malinen E, Palva A, Varmanen P: Characterization of a mobile clpL gene from Lactobacillus rhamnosus. Appl Environ Microbiol 2005, 71:2061-2069.

120. Suokko A, Poutanen M, Savijoki K, Kalkkinen N, Varmanen P: ClpL is essential for induction of thermotolerance and is potentially part of the HrcA regulon in Lactobacillus gasseri. Proteomics 2008, 8:1029-1041.

121. Fiocco D, Collins M, Muscariello L, Hols P, Kleerebezem M, Msadek T, Spano G: The Lactobacillus plantarum fts $\mathrm{H}$ gene is a novel member of the CtsR stress response regulon. J Bacteriol 2009, 191:1688-1694.

122. Savijoki K, Suokko A, Palva A, Valmu L, Kalkkinen N, Varmanen P: Effect of heat-shock and bile salts on protein synthesis of Bifidobacterium longum revealed by [35S]methionine labelling and two-dimensional gel electrophoresis. FEMS Microbiol Lett 2005, 248:207-215.

123. Ventura M, Canchaya C, Zink R, Fitzgerald GF, van Sinderen D: Characterization of the groEL and groES loci in Bifidobacterium breve UCC 2003: genetic, transcriptional, and phylogenetic analyses. App/ Environ Microbiol 2004, 70:6197-6209.

124. Ventura M, Fitzgerald GF, van Sinderen D: Genetic and transcriptional organization of the $\mathrm{clpC}$ locus in Bifidobacterium breve UCC 2003. Appl Environ Microbiol 2005, 71:6282-6291.

125. Ventura M, Zhang Z, Cronin M, Canchaya C, Kenny JG, Fitzgerald GF, van Sinderen D: The ClgR protein regulates transcription of the clpP operon in Bifidobacterium breve UCC 2003. J Bacteriol 2005, 187:8411-8426.

126. Ventura M, Canchaya C, Zhang Z, Fitzgerald GF, van Sinderen D: Molecular characterization of $h s p 20$, encoding a small heat shock protein of Bifidobacterium breve UCC2003. Appl Environ Microbiol 2007, 73:4695-4703.

127. Serror P, Dervyn R, Ehrlich SD, Maguin E: csp-like genes of Lactobacillus delbrueckii ssp. bulgaricus and their response to cold shock. FEMS Microbiol Lett 2003, 226:323-330.

128. Wang Y, Delettre J, Guillot A, Corrieu G, Beal C: Influence of cooling temperature and duration on cold adaptation of Lactobacillus acidophilus RD758. Cryobiology 2005, 50:294-307.

129. Ventura M, Zink R, Fitzgerald GF, van Sinderen D: Gene structure and transcriptional organization of the dnaK operon of Bifidobacterium breve UCC 2003 and application of the operon in bifidobacterial tracing. Appl Environ Microbiol 2005, 71:487-500.

130. Ventura M, Canchaya C, Bernini V, Del Casale A, Dellaglio F, Neviani E, Fitzgerald GF, van Sinderen D: Genetic characterization of the Bifidobacterium breve UCC 2003 hrcA locus. Appl Environ Microbiol 2005, 71:8998-9007.

131. Lambert JM, Bongers RS, de Vos WM, Kleerebezem M: Functional analysis of four bile salt hydrolase and penicillin acylase family members in Lactobacillus plantarum WCFS1. Appl Environ Microbiol 2008, 74:4719-4726.

132. Price CE, Reid SJ, Driessen AJ, Abratt VR: The Bifidobacterium longum NCIMB 702259T ctr gene codes for a novel cholate transporter. Appl Environ Microbiol 2006, 72:923-926.

133. Wall T, Bath K, Britton RA, Jonsson H, Versalovic J, Roos S: The early response to acid shock in Lactobacillus reuteri involves the ClpL chaperone and a putative cell wall-altering esterase. Appl Environ Microbiol 2007, 73:3924-3935

134. De Angelis M, Bini L, Pallini V, Cocconcelli PS, Gobbetti M: The acid-stress response in Lactobacillus sanfranciscensis CB1. Microbiology 2001, 147:1863-1873.

135. Azcarate-Peril MA, McAuliffe O, Altermann E, Lick S, Russell WM, Klaenhammer TR: Microarray analysis of a two-component regulatory system involved in acid resistance and proteolytic activity in Lactobacillus acidophilus. Appl Environ Microbiol 2005, 71:5794-5804.

136. Kullen MJ, Klaenhammer TR: Identification of the $\mathrm{pH}$-inducible, protontranslocating F1F0-ATPase (atpBEFHAGDC) operon of Lactobacillus acidophilus by differential display: gene structure, cloning and characterization. Mol Microbiol 1999, 33:1152-1161. 
137. Ventura M, Canchaya C, van Sinderen D, Fitzgerald GF, Zink R: Bifidobacterium lactis DSM 10140: identification of the atp (atpBEFHAGDC) operon and analysis of its genetic structure, characteristics, and phylogeny. Appl Environ Microbiol 2004, 70:3110-3121.

138. Sanchez B, Ruiz L, de los Reyes-Gavilan CG, Margolles A: Proteomics of stress response in Bifidobacterium. Front Bioscience 2008, 13:6905-6919.

doi:10.1186/1475-2859-10-S1-S19

Cite this article as: Mills et al: Enhancing the stress responses of probiotics for a lifestyle from gut to product and back again. Microbial Cell Factories 2011 10(Suppl 1):S19.

Submit your next manuscript to BioMed Central and take full advantage of:

- Convenient online submission

- Thorough peer review

- No space constraints or color figure charges

- Immediate publication on acceptance

- Inclusion in PubMed, CAS, Scopus and Google Scholar

- Research which is freely available for redistribution

Submit your manuscript at www.biomedcentral.com/submit
C Biomed Central 